\title{
Marionaima inaugurou a musicologia no Brasil
}

Marionaíma (Mário de Andrade) inaugurated Brazilian musicology

\section{Marcus vinicius de andiade*}

DOI: https://doi.org/10.4322/principios.2675-6609.2022.163.006

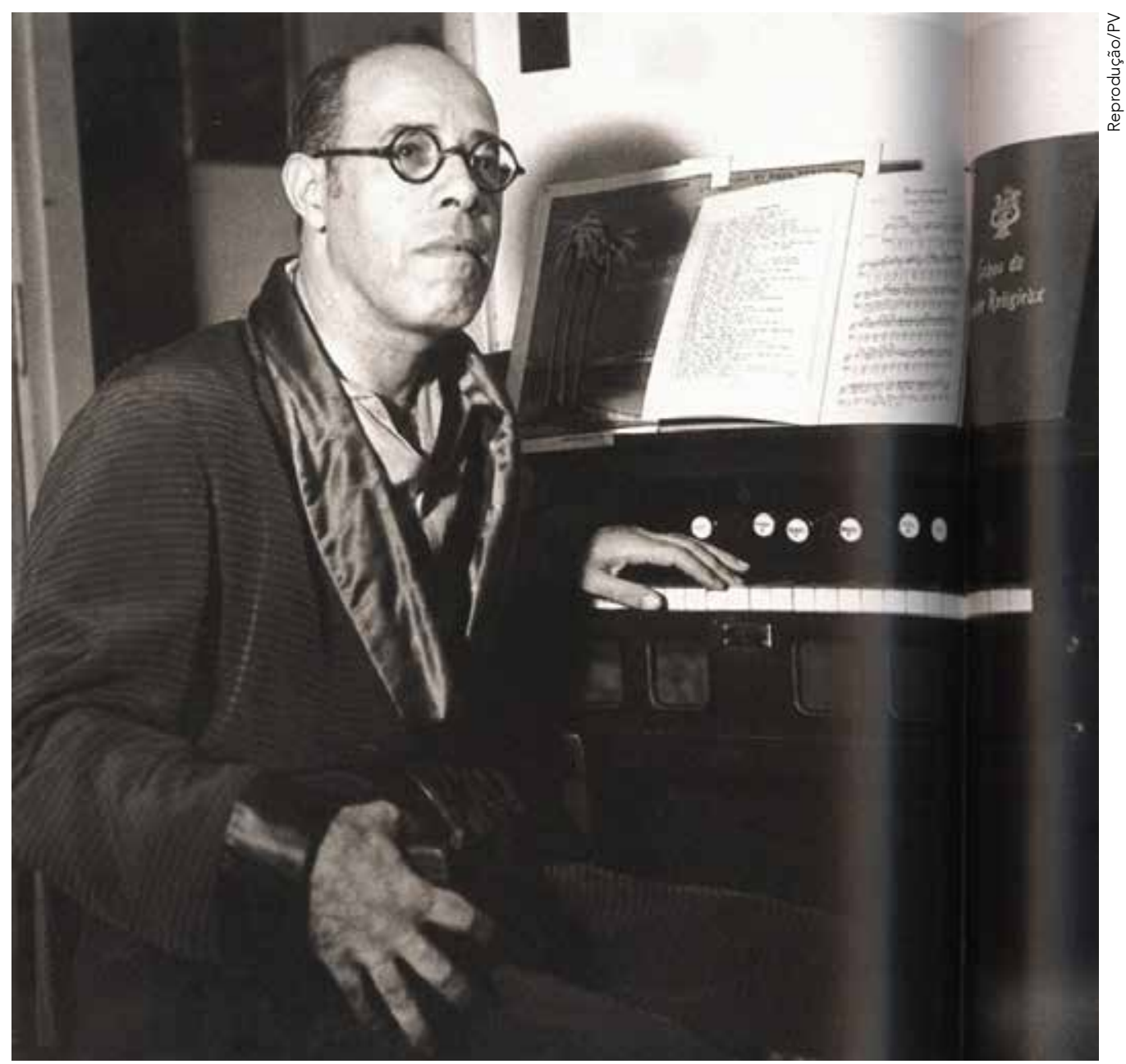

Escritor, crítico e ensaísta, autor do clássico Macunaíma (1928), Mário de Andrade também se notabilizou como precursor da musicologia no Brasil 


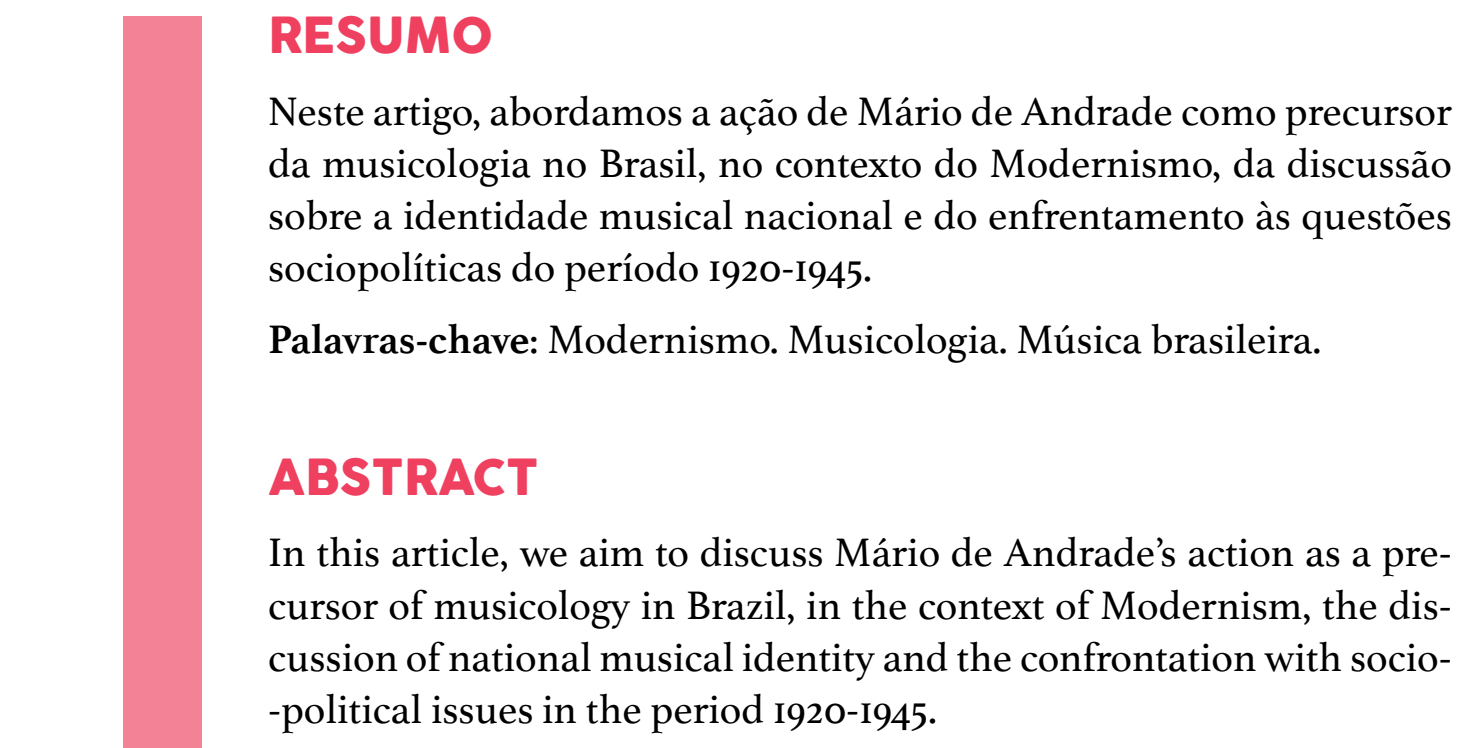

Keywords: Modernism. Musicology. Brazilian music. 


\section{INTRODUCÃ̃: PRELÚDIO AO FUTURO}

Durante o velório de Mário de Andrade, Edgard Cavalheiro me perguntou, no jardinzinho que havia na frente da casa: "Para encontrar na literatura brasileira uma morte desta importância é preciso voltar até quando?". Respondi: "Até a morte de Machado de Assis."

Antonio Candido (MÁRIO..., 2005)

Falecido aos 5I anos, a 25 de fevereiro de 1945, na mesma cidade de São Paulo que o vira nascer a 9 de outubro de I893, Mário Raul de Morais Andrade, que assinava suas obras apenas como Mário de Andrade, foi sepultado no Cemitério da Consolação em meio às homenagens de uma multidão de amigos, parentes, admiradores e anônimos, entre os quais haveria até viventes daquele Brasil que não conhecia o Brasil e nunca fora ao Brasil, como diriam, décadas mais tarde, os compositores Maurício Tapajós e Aldir Blanc, num samba célebre por prever o passado e em que também reverenciavam a figura maior de um herói com todo o caráter, por eles identificado como Marionaíma. Que outro não era se não o Mário ora em questão, poeta, contista, romancista, fotógrafo, historiador e crítico de arte, um dos fundadores do Modernismo no país, festejado nacional e internacionalmente como criador de obras fundamentais como Macunaíma, Pauliceia desvairada, Amar, verbo intransitivo e muitas outras —, mas que, apesar de seus talentos de polígrafo (ou polímata, como querem hoje alguns empedernidos), é pouco ou nada lembrado como precursor da musicologia brasileira. O que não é pouco, muito pelo contrário.

Adolescente prodígio que sonhava ser músico profissional, Mário disputava desafios de virtuosismo pianístico com o irmão Renato: mas com o falecimento deste, em I9I3 (aos I4 anos, após um acidente sofrido enquanto jogava futebol), Mário ficou emocionalmente abalado e passou a ter um leve tremor nas mãos, que o fez desistir da carreira de pianista, para a qual estava se preparando desde I9II, quando ingressara no Conservatório Dramático e Musical de São Paulo (CDMSP), aos I8 anos. Não desistiria da música, no entanto: abraçou a pedagogia e logo se tornou professor substituto de História da Música, passando a ser (c. 1916) professor auxiliar de piano até formar-se em 1917. Em 1922, quando ressoavam os tambores da revolução modernista, Mário foi efetivado na cátedra de Estética e História da Música do mesmo Conservatório Dramático e Musical de São Paulo, em que faria carreira e permaneceria até sua morte, excetuado o período em que residiu no Rio de Janeiro (I938-I94I).

Embora não tivesse formação acadêmica comparável à dos tempos atuais (ainda que o CDMSP fosse, à época, a primeira escola superior do gênero na cidade de São Paulo e a quarta do país, antecedido apenas pelo Conservatório de Música do Rio de Janeiro, pelo Conservatório Carlos Gomes de Belém do Pará e pelo Instituto de Música da Bahia, fundados respectivamente em I84I, I895 e I897), Mário de Andrade, 
pesquisador aplicado e leitor contumaz, possuía sólida cultura literária e humanística, que, acumulada ao conhecimento técnico-musical aprendido no conservatório, lhe conferia uma condição intelectual diferenciada e própria para enveredar pelos misteres da musicologia brasileira, que então se buscava construir.

Nascido numa família da média burguesia paulista de fins do século XIX, nutrida na fé católica e na moral conservadora e que, como toda a sociedade brasileira da época, vivia, ainda que inconscientemente, no dizer da prof. ${ }^{a}$ dra. Telê Ancona Lopez, "a contradição sutil entre conservadorismo ético e liberalismo político" (LOPEZ, I972, p. 2I), Mário recebeu orientação religiosa quando aluno de um colégio de irmãos maristas em São Paulo, depois tornando-se membro da Congregação Mariana da Igreja de Santa Ifigênia, de cujas procissões públicas participava contrito, trajando opa, casula e demais paramentos. Sua assumida carolice não impediu que, alguns anos mais tarde, associasse seus estudos de folclore ao marxismo, neste buscando os fundamentos econômicos que lhe permitiriam melhor compreender o povo e suas manifestações. As contradições de Mário quanto a assumir a prática católica em conjunto com ideias marxistas foram (e ainda são) objeto de percucientes considerações de Telê Ancona Lopez e outros estudiosos, como se sabe.

Estas não eram, porém, as únicas contradições daquele que chegaria a ser considerado o pai do Modernismo brasileiro e cujas ideias, segundo consta, eram explanadas até mesmo com certo descuido e destemor, o que levou o crítico, compositor e ensaísta José Miguel Wisnik a nele identificar uma tendência para negar e/ou afirmar coisas contraditórias em curtíssimo espaço de tempo, já que

sua consciência parece viver subterraneamente as contradições, mesmo quando a proposta de uma ação cultural imediata tende a eliminá-las ou atenuá-las para tentar avançar (WISNIK, I977, p. IO5).

No entanto, o vaivém de incongruências, instabilidades e contradições não deveria aplicar-se apenas a Mário e a seus companheiros de modernidade, isoladamente. Em I9I7, quando o movimento teria tido, historicamente, seus primeiros impulsos, tanto o mundo como o Brasil já viviam uma nova era: estávamos num século novo, nos tempos da eletricidade, do telefone, do telégrafo, do cinema, do automóvel, do avião; a belle époque começava a ser vista pelo retrovisor; entrávamos no período que seria marcado pelos dois maiores conflitos bélicos do século, a primeira e a segunda guerras mundiais (I9I4-I8 e I939-I945), que aposentaram impérios e colônias, destronaram dinastias e redesenharam a geopolítica do planeta sem que se precisasse afirmar que a Terra era plana; em muitas partes do mundo, mulheres, minorias e explorados de toda sorte começavam a lutar por direitos democráticos e laborais e, sobretudo, a conquistá-los; na velha Rússia, passava a tremular, vitoriosa, a bandeira vermelha dos sovietes; no Brasil, I9I7 foi o ano da primeira grande greve operária, que, embora liderada principalmente por anarquistas, significou o grito pioneiro do proletariado organizado no país, do qual cinco anos depois resultaria a criação do 


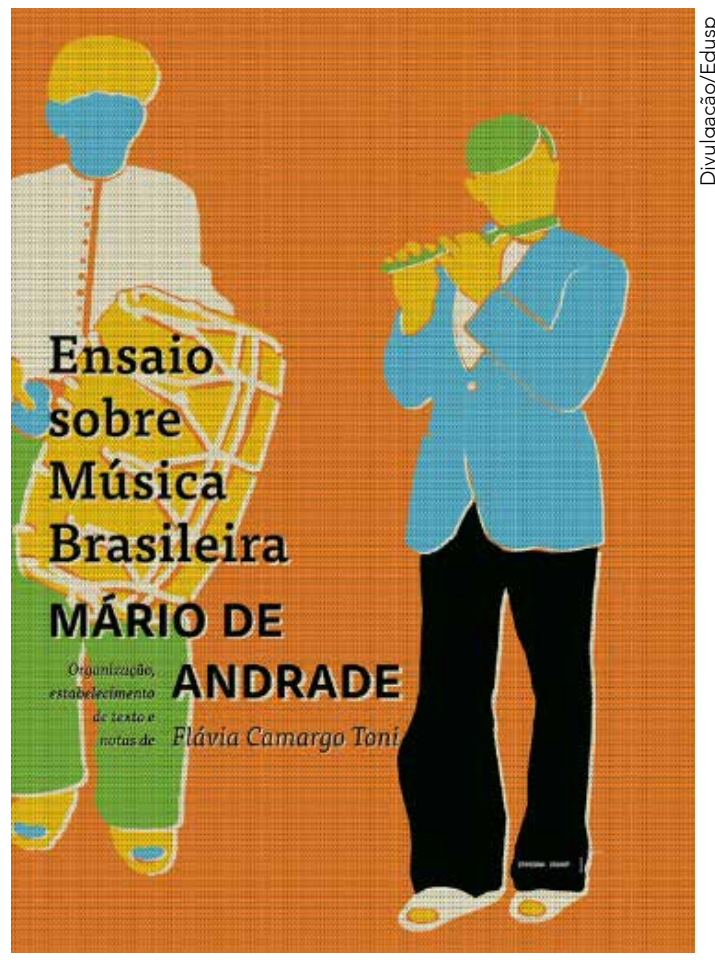

Capa da segunda edição de Ensaio sobre música brasileira, lançada pela Edusp em 2020 e organizada por Flávia Camargo Toni

Partido Comunista do Brasil e a eclosão do ciclo revolucionário do tenentismo, que culminou com a Revolução de 1930, o fim da República Velha e a ascensão de Getúlio Vargas ao poder.

Era muita mudança acontecendo de uma vez só e não se podia esperar que Mário de Andrade e seus modernos, mesmo sem querer, não se deixassem impactar pelas nouveautés que surgiam a cada esquina e persistissem nos mesmos pensamentos, ideias e valores cultivados no já velho e distante século XIX. Inclusive porque, à exceção de luminares como Graça Aranha e outros poucos, os futuros modernistas da primeira hora integravam também a primeira geração de artistas a chegar à maioridade durante a República e tinham de fazer jus a tal condição. Afinal, os padrões estéticos, as práticas sociopolíticas, modas e hábitos pessoais e familiares estavam mudando em todo o mundo, não se admitindo que a Botocúndia aqui, denunciada por Lobato (até por ele!), resistisse aos novos tempos e se recusasse teimosamente a ir para a sepultura. Especialmente no campo da cultura e da arte, havia muito o que fazer, a começar por trazê-las para a vida real, retirando-as do mofo bacharelesco dos institutos históricos, sociedades e salões literários, arcádias, ateneus e grêmios movidos a comendas e medalhas, para que fossem introduzidas no trepidante mundo do maxixe, do Carnaval, do ragtime, das melindrosas, dos dândis e malandros, das lutas e festas populares - do novo Brasil que se anunciava, enfim.

Tantas transformações não podiam ocorrer, claro, sem que aflorassem, entre os modernistas, rivalidades e conflitos de toda ordem (ou desordem), inerentes ao novo tempo que se abria. O mais conhecido de tais conflitos talvez tenha sido o que, 
em 1929, opôs e separou os dois Andrades, Mário e Oswald, os papas modernistas que jamais se reconciliaram para valer, apesar das tentativas do último. A quem interessar possa, hoje há até produções acadêmicas que tratam das divertidas polêmicas, confusões, intrigas e arranca-rabos entre os aspirantes ao Olimpo do Modernismo brasileiro, tal como o ensaio publicado por Leandro Garcia Rodrigues, doutor em Letras pela PUC-Rio (RODRIGUES, 20I3).

Naquele ano de I9I7, porém, os olhos da elite brasileira, principalmente os dos seus artistas e intelectuais, voltavam-se basicamente para a Europa, onde tudo acontecia, aliás. Inclusive uma certa Guerra Mundial, que demoraria ainda cerca de um ano para ter fim. Enquanto isso não ocorria, a Europa continuava a dar as cartas ao mundo em termos de música, literatura, poesia, artes plásticas, dança etc. — enfim, de tudo que significasse bom gosto, ousadia, qualidade e refinamento estético, para mostrar que a vida valia a pena, ainda que suas benesses não chegassem a todos. Enquanto grande parte do planeta afundava em jequice, a velha Europa, notadamente a França, esbanjava cultura, vanguarda e civilização, servindo de exemplo para o mundo, inclusive para um certo Grupo dos Cinco, que, no longínquo Brasil, tentava emular Les Six, o célebre grupo francês de música moderna, composto por Germaine Tailleferre, Georges Auric, Louis Durey, Arthur Honegger, Jean Cocteau e Darius Milhaud.

Já o brasileiríssimo Grupo dos Cinco era formado por Tarsila do Amaral, Anita Malfatti, Oswald de Andrade, Menotti del Picchia e Mário, o qual jamais foi à Europa: por sinal, jamais saiu do Brasil. Mas renovar as artes e a literatura era o desígnio claro de todos os membros do grupo e dos artistas e intelectuais com quem conviviam, tanto aqui como na Europa, parecendo certo terem sido eles que levaram a proposta da Semana àquele que realmente seria seu grande idealizador e promotor: o cafeicultor, megaempresário e escritor Paulo Prado, descendente de uma das mais influentes famílias paulistanas, que por muitos anos residiu em Paris, onde seu apartamento, à Rue de Rivoli, tornou-se um dos points da vida cultural local.

Prado comprou a ideia de pronto, por razões que depois foram explicitadas pelo próprio Mário de Andrade na célebre entrevista concedida em abril de 1942, no salão de conferências da Biblioteca do Ministério de Relações Exteriores (Palácio do Itamaraty), na qual o escritor fez como que um mea-culpa e talvez a mais contundente crítica à Semana de Arte Moderna de I922, na época comemorando 20 anos.

Tomada a decisão de realização da Semana, Prado autorizou o advogado e escritor Renê Thiollier a tomar as providências necessárias ao evento, inclusive pagar o aluguel do Teatro Municipal de São Paulo, contratar e remunerar funcionários e artistas, administrar a venda de ingressos ao público e passar o "livro de ouro" pela sociedade, para recolher contribuições de empresários e amigos dispostos a colaborar com a ousadia a ser feita. Os recibos dos aluguéis do Municipal foram emitidos em nome de Thiollier, segundo os herdeiros deste, que guardaram tais documentos.

Tudo pronto, de I3 a I7 de fevereiro de I922, abriram-se as portas e cortinas do Municipal para o evento modernista, havendo hoje farta documentação pública e 
registros do que ali ocorreu. E não foi pouca coisa. Houve de tudo: poemas recitados ao som de miados, latidos e cacarejos do público; coaxar da plateia ao ouvir "Os Sapos”, de Manuel Bandeira, recitado por Ronald de Carvalho; o maestro Villa-Lobos trajando casaca e calçado com um único sapato, pois o outro pé, descalço, ostentava um vistoso curativo, que não era modernice, era verdade mesmo...

Ao final, salvaram-se todos: principalmente a cultura brasileira.

A História está aí para contar a história.

\section{NO FUNDO DO MATO VIRGEM, NASCE UM MUSICÓLOGO}

Ante o sucesso retumbante da Semana de Arte Moderna, que só anos depois começaria a ressoar para sempre, alguém poderia dizer: "É, mas também não faltou dinheiro, não faltou nada..."

Faltou, sim. Faltou povo. Era preciso ir atrás dele, conhecê-lo bem. Principalmente em termos musicais.

Mesmo tendo exercido o jornalismo de I9I3 até o final de sua vida (inclusive cumprindo, com alguma regularidade, a função de crítico de música no jornal $A$ Gazeta, de São Paulo, no ano de I9I8), Mário de Andrade não podia, ao início dos anos I920, ser considerado sequer um projeto de musicólogo, visto que tal especialidade era ainda incipiente no meio acadêmico das primeiras décadas no século XX e simplesmente inexistia no campo jornalístico. Era assim no Novo Mundo havia quase dois séculos. No entanto, na Ibero-América (Brasil incluído), foi na imprensa periódica que começaram a surgir os primeiros textos de caráter histórico-musical, outrora qualificados como simples esboços, apontamentos ou noções, destinados apenas a despertar, quem sabe, o interesse de futuros candidatos a historiador. Nesse aspecto, Mário não fugiu ao destino comum a muitos outros estudiosos da música nacional de seus países, padecendo com a carência de fontes bibliográficas adequadas, de documentação suficiente, de historiografias confiáveis e, sobretudo, de estudos sobre as peculiaridades técnicas da música de seus povos e nações.

Com certeza, quase todos os estudiosos ibero-americanos começaram a estudar e a escrever sobre sua música nacional e popular catando referências possíveis em historiadores, geógrafos, dicionaristas, etnógrafos, folcloristas, lexicógrafos, viajantes, cronistas e quaisquer outros intelectuais que algum dia se aproximaram do universo da cultura tradicional e popular. Os hispanohablantes sempre tiveram a vantagem de contar com uma maior dispersão de sua língua, bem como com a robustez de suas produções editoriais, que circulavam na maior parte do Novo Mundo de forma quase unificada. O mesmo não ocorreu com os viventes da América portuguesa, ou seja, nós do Brasil - que, além de isolados pelo idioma, sofremos historicamente com as limitações de Portugal à implantação e expansão da imprensa e do livro em nosso território.

Enquanto, desde os tempos da Colônia, um razoavelmente grande número de compêndios e tratados de música e história musical podiam ser acessados com re- 
Mário de Andrade e seu padrinho político Paulo Duarte filiaram-se oficialmente aos democráticos e, de forma até surpreendente, afastaram-se dos segmentos da elite com quem até então circulavam com desenvoltura para iniciar uma trajetória progressista, que logo mais os levaria a engajarem-se na campanha presidencial que levaria Getúlio Vargas à Presidência do país. Para Mário, isso aos poucos foi significando uma opção pelas ideias de esquerda, até mesmo marxistas

lativa facilidade pelos estudiosos ibero-americanos, no Brasil, os pretendentes a historiador musical ou mesmo a musicólogo - Mário de Andrade entre eles - tinham de contentar-se com o pouco que lhes chegava às mãos. Em geral, suas fontes sobre o país se restringiram a autores e cronistas coloniais (Antonil, Gaspar Barléu, frei Jaboatão, Gabriel Soares de Sousa, Gândavo, frei Vicente de Salvador, Jean de Léry, Fernão Cardim, padre Simão de Vasconcelos et alii), jesuítas em catequese (como Manoel da Nóbrega e Anchieta) e viajantes (principalmente Koch-Grünberg, Spix, Martius e Henry Koster, além de outros), passando depois a historiadores clássicos (Rocha Pita, Varnhagen, Capistrano de Abreu) e críticos literários (Silvio Romero, José Veríssimo, Araripe Júnior etc.), só mais tarde incorporando-se à lista alguns autores contemporâneos de então. De músicos, apenas Sigismund Neukomm, Louis Moreau Gottschalk e, com alguma tolerância, outros muito poucos. Como plantar uma semente de consciência musicológica num quadro quase vazio de músicos, a não ser que fosse para dar corpo à inteligente blague do prof. Rafael Menezes Bastos, que certo dia lamentou a possibilidade de ter-se uma antropologia sem música e uma musicologia sem homem?

À época da Semana de 22 e nos anos seguintes, a base referencial de Mário de Andrade, especialmente no campo do folclore, acolhia também autores como Mello Morais Filho, Silvio Romero, Alexina Magalhães Pinto e Amadeu Amaral, além de tratadistas portugueses clássicos, em geral lexicógrafos e/ou autores com viés enciclopédico, tais como Carolina Michaelis, Leite de Vasconcelos e Teófilo Braga, principalmente. Registre-se que, quanto à bibliografia musical, era comum e praticamente inevitável no Brasil daquela época o uso de enciclopédias e tratados portugueses, visto que o primeiro livro sobre a história da música no país teria sido A música no Brasil desde os tempos 
da Colônia ao primeiro decênio da República, publicado em Salvador no ano de 1908, com autoria de Guilherme Theodoro Pereira de Mello (PEREIRA DE MELLO, I908).

Essa obra foi referenciada inúmeras vezes por Mário de Andrade como item de sua biblioteca particular, hoje depositada no acervo do Instituto de Estudos Brasileiros (IEB), da USP. Parece haver algum equívoco, porém, quanto ao Diccionario musical, de Raphael Coelho Machado, o primeiro dicionário musical publicado no Brasil (I842), sobre o qual, embora constando do mesmo acervo, não há qualquer indício de que tenha provindo da biblioteca pessoal de Mário, nem que este o tenha utilizado em seus estudos, o que seria de lamentar em se tratando de uma publicação pioneira e rara, da qual o mais importante musicólogo do nosso país não teria tomado conhecimento.

Por fim, como prova do zelo de Mário por suas fontes bibliográficas, cabe destacar o precioso resgate lexicográfico feito por ele e seus colaboradores a partir do Diccionario da lingua portugueza (I ${ }^{\mathrm{a}}$ edição em I789 e $2^{\mathrm{a}}$ edição em I813), organizado por Antonio de Moraes Silva, brasileiro nascido no Rio de Janeiro e formado em Portugal. Tal obra teve (tem) fundamental importância por complementar os oito tomos do pioneiro Vocabulario portugues e latino, do padre Raphael Bluteau, publicado em Portugal entre I7I2 e I728, sendo até hoje preciosa fonte para o estudo do que era o léxico musical da lusofonia nos séculos XVII e XVIII.

Foi através do conhecimento de todos esses clássicos e do que eles representavam que Mário de Andrade, na esteira da curiosidade inventiva preconizada pelo Modernismo, percebeu que já era tempo de arregaçar as mangas e ir logo aonde o povo estava, para ouvir sua música "em cores e ao vivo", direto na veia.

\section{A CAMINHO DA LUTA}

Em I919, Mário realizara, sozinho, sua primeira viagem ao interior de Minas Gerais. Após ter assistido, em I9I4, a uma conferência sobre arte tradicional do Brasil, proferida na Sociedade de Cultura Artística de São Paulo pelo engenheiro, arqueólogo (e talvez foragido político) português Ricardo Severo, Mário teria viajado para estudar a arquitetura colonial de Mariana, Ouro Preto, Congonhas e São João del-Rei, aproveitando também para conhecer o poeta de sua predileção à época, Alphonsus de Guimaraens. Dessa viagem resultariam quatro artigos de Mário para a Revista do Brasil, publicados no primeiro semestre de $\mathbf{1 9 2 0}$, e a descoberta do prazer do poeta em viajar como turista para "aprender o Brasil", o que ele gostaria de fazer com frequência, depois da Semana de Arte Moderna.

Isso não demorou muito a ocorrer, aliás. Já em abril de 1924, antes que as tropas, baionetas e bombas do general Isidoro Dias Lopes marcassem presença na capital paulista, Mário de Andrade voltaria às terras mineiras, desta feita à frente de um grupo formado por d. Olivia Guedes Penteado, Oswald de Andrade e seu filho Nonê, Tarsila do Amaral, Renê Thiollier, o advogado Gofredo da Silva Telles e o poeta franco-suíço Blaise Cendrars (que de tanto estar por aqui já estava sendo chama- 
do de terceiro elemento do Movimento Pau-Brasil), além de Paulo Prado, dizem. Há controvérsias, porém.

Os anos que antecederam a chegada de 1930 foram de intensa agitação em São Paulo. Na esteira do êxito, mesmo discutível e polêmico, da Semana de Arte Moderna, um câmbio geracional se configurava e novos nomes (com sobrenomes não tão ilustres, nem contas bancárias tão recheadas) preparavam-se para a troca de guarda em quase todos os segmentos socioeconômicos do estado. Em razão disso, novos consensos políticos foram se formando, enquanto outros rapidamente se esfumaram, para mostrar que tudo que é sólido desmancha etc. etc. etc. Para fazer oposição ao cristalizado Partido Republicano Paulista, em fevereiro de 1926 foi fundado o Partido Democrático, sob a liderança do Conselheiro Antonio Prado e de um grupo de próceres que pareciam estar ali só mesmo para confirmar que nada era mais igual a um luzia que um saquarema... Havia exceções, porém: descontentes com os carcomidos do PRP, Mário de Andrade e seu padrinho político Paulo Duarte filiaram-se oficialmente aos democráticos e, de forma até surpreendente, afastaram-se dos segmentos da elite com quem até então circulavam com desenvoltura para iniciar uma trajetória progressista, que logo mais os levaria a engajarem-se na campanha presidencial que levaria Getúlio Vargas à Presidência do país. Para Mário, isso aos poucos foi significando uma opção pelas ideias de esquerda, até mesmo marxistas, que ele acolheu de forma sincera, embora reservada e não ostensiva. Não tão reservada assim: há que lembrar o entusiasmo de Mário quando, a respeito da forte chuva que caiu em São Paulo durante a passeata que saudou a chegada dos candidatos da Aliança Liberal à cidade, registrou em crônica a euforia do canto coletivo da multidão nas ruas: "Até debaixo d'água/ Getúlio e João Pessoa!" (TRAVASSOS, I997, p. 12).

Euforia que era também a dele próprio, como se viu depois.

Mas antes que a Revolução de 1930 propriamente dita entrasse na ordem do dia, Mário, sozinho, deflagraria duas revoluções pessoais no campo da cultura, que também ajudariam a mudar a cara do Brasil.

Uma delas foi o lançamento do romance-rapsódia Macunaíma, em I928, sobre o qual muito se tem falado nos últimos 94 anos, sendo desnecessária qualquer repetição. A outra revolução, esta mais discreta mas igualmente relevante, foi a publicação, no mesmo ano, do Ensaio sobre a música brasileira, com o qual Marionaíma inauguraria a moderna musicologia nacional, tirando a reflexão sobre nossa cultura musical das mãos dos diletantes e trazendo-a para quem entendia profissionalmente do assunto.

Os principais aspectos levantados no Ensaio dizem respeito basicamente à questão da identidade musical nacional, item predominante, aliás, na maior parte das indagações dos musicólogos latino-americanos de inícios do século passado. No caso brasileiro, tal questão seria emblemática da segunda fase do nosso movimento modernista, a fase em que se buscou a construção nacional propriamente dita, como mais bem explicitado nas palavras da musicóloga Elizabeth Travassos:

O movimento modernista brasileiro costuma ser dividido em duas fases: a primeira, entre 1917 e 1924, foi de atualização das linguagens artísticas, heroica, demolidora, 


\section{Antes que a Revolução de 1930 propriamente dita entrasse na ordem do dia, Mário, sozinho, deflagraria duas revoluções pessoais no campo da cultura, que também ajudariam a mudar a cara do Brasil}

carismática, e privilegiou o problema das artes; a segunda, entre I924 e 1929, foi de construção nacional, consolidação das conquistas e abertura para os problemas da sociedade, tendendo à politização (TRAVASSOS, I997, p. I2).

Como se vê, essa análise em tudo justifica a "guinada progressista" que Mário adotou a partir de 1926, quando, segundo Telê Ancona Lopez, ele amadureceu um projeto nacionalista para ir "progressivamente abrangendo e sulcando o projeto ideológico" (LOPEZ, 1972). Ainda segundo Telê, Mário teria ampliado seu entendimento da cultura por meio das viagens que fez ao Norte e Nordeste do Brasil.

Nesse mesmo diapasão, Maria Elisa Pereira entende que, com as publicações de Macunaíma e Ensaio sobre a música brasileira, o ano de 1928 seria o demarcador do projeto ideológico de Mário, enquanto I 922 ficaria marcado como o ano de seu plano estético (PEREIRA, 2006, p. 34-35).

Como dito, desde as primeiras publicações de obras latino-americanas sobre música e cultura musical no Novo Mundo, os estudiosos esgrimem dúvidas conceituais, buscando enquadramentos taxonômicos precisos para definir as diversas formas como os fenômenos musicais se manifestam. A mais inquietante e persistente dessas dúvidas diz respeito à definição do que é música popular, música folclórica, música erudita, música popularesca e equivalentes.

Ainda que seja difícil estabelecer distinções rigorosas entre tais categorias, próximas ou distantes entre si em maior ou menor grau, tem-se que o conceito de música popular, por exemplo, figura hoje na historiografia musical latino-americana como um conceito já polissêmico, que, embora nascido em contextos históricos particulares, neles sofreu transformações de significado, até tornar-se algo plural e indefinido na atualidade.

Mas até pouco tempo atrás não era assim. Em espanhol, música popular vinculava-se a pueblo, que tanto significa "povo", como "povoado", "aldeia" etc., o que dava um recorte sociogeográfico ao conceito, dele excluindo tudo que não estivesse no âmbito das pequenas comunidades. Em seguida, o conceito foi-se confundindo com o de música folclórica (afinal tudo é música del pueblo, não?), no entanto exigindo-se para esta o atributo de ser criação anônima e oral, o que já não mais ocorre obrigatoriamen- 
te de uns tempos para cá. Com o termo música erudita, aplicado à música de tradição escrita, difundida nas igrejas e/ou em ambientes de saber, riqueza ou poder, criava-se um critério de exclusão socioeconômica da música popular, que assim foi apresentada à luta de classes. Buscou-se também agir como se todas essas categorias musicais não intercambiassem valores e não estivessem submetidas às contingências da circularidade cultural, o que só aumentava a dificuldade de estabelecer conceitos precisos e exclusivos para o que era, naturalmente, amplo e genérico. Com isso, música popular passou a ser dada como tudo aquilo que era produzido à feição do povo ou sob inspiração dele, o que só fez aumentar a confusão, que já não era pouca. E as coisas pioraram quando passou a existir a música de grande consumo, produto da indústria cultural e difundida comercialmente por meio de discos, rádios etc., que muitos estudiosos (Mário, inclusive) enquadraram como música popularesca, populachera ou mesmo como submúsica (Mário, inclusive). Outros musicólogos, como o argentino Carlos Vega, chegaram mesmo a cunhar novas classificações, como a de mesomúsica, para acolher as expressões musicais híbridas, como, por exemplo, as mesclas de música popular e música folclórica, ou de música erudita e música popular.

Com o tempo, muitos desses conceitos foram mudando ante a emergência de novos modelos de produção e difusão musical. Mário de Andrade, infelizmente, faleceu em I945, sem ter podido ver o câmbio e a relativização das classificações musicais ou mesmo sua definitiva superação ou descarte conceitual. Mas consola saber que ele legou ensinamentos preciosos a uma moderna musicologia brasileira, deixando também continuadores em seus discípulos diretos (principalmente a grande Oneyda Alvarenga, falecida em 1984), além dos novos expoentes do saber musicológico e/ou etnográfico do país, entre os quais Telê Ancona Lopez e Claudia Camargo Toni, as principais preservadoras da obra, da memória e do acervo mariodeandradeano no Iseb-USP, além de José Miguel Wisnik, Rafael Menezes Bastos, Elizabeth Travassos (in memoriam), Paulo Castagna, Manuel Veiga, José Geraldo Vinci de Moraes, Rogério Budasz, Martha Abreu, José Ramos Tinhorão (in memoriam), Martha Tupinambá, Hugo Ribeiro, José Jorge Carvalho, Mercedes Reis Pequeno (in memoriam), Alberto Ikeda e Tania Costa Garcia, entre outros, isso para não falar da icamiaba paulista-colombiana Juliana Pérez González, a quem o Brasil deve um muiraquitã por sua dedicação à música da Latino-América.

Não caberia encerrar este trabalho sem mencionar aquelas que julgamos serem as principais contribuições de Mário de Andrade à cultura do país:

- $\quad$ sua vasta e inestimável obra de polímata (vá lá...);

- a elaboração, em 1936, do anteprojeto de criação do Sphan (Serviço do Patrimônio Histórico e Artístico Nacional — hoje Iphan);

- a idealização e a criação, em 1935, juntamente com Paulo Duarte, do Departamento de Cultura da Cidade de São Paulo, através do qual foram executados projetos culturais referenciais como a Missão de Pesquisas Folclóricas (I937-I938), historicamente a mais relevante iniciativa em prol da cultura popular brasileira, e o Congresso da Língua Nacional Cantada (I937). 
Todas essas iniciativas, ainda que já tenham sido divulgadas, inclusive internacionalmente, continuam merecedoras de maiores estudos, o que julgamos urgente, para que sua memória não se perca aos poucos.

* Maestro, compositor, musicólogo e dramaturgo. Licenciado em Música (Composição e Regência) pelo Instituto Villa-Lobos da antiga Fefierj em 1971. Ministrou na mesma instituição as cadeiras de Análise Musical e Orquestração entre 1972 e 1973, quando foi afastado do magistério pelo regime militar. Lecionou as mesmas disciplinas nos cursos superiores da Academia Paulista de Música e do Instituto Musical São Paulo (1973-1978). Diretor Artístico da Discos Marcus Pereira, gravadora especializada na pesquisa da música brasileira tradicional (1977-1982). Diretor da Divisão de Pesquisas do Centro Cultural São Paulo - CCSP -, da Secretaria Municipal de Cultura, órgão que assumiu o resgate histórico da Missão de Pesquisas Folclóricas criada por Mário de Andrade em 1937, cujo acervo esteve indisponível, por razões políticas, até 1987, pertencendo hoje à Biblioteca Oneyda Alvarenga do CCSP. Membro Titular do Conselho Nacional de Direito Autoral - CNDA - do Ministério da Cultura (19821988) e do Conselho Superior de Defesa da Liberdade de Criação e Expressão - Codeliber - do Ministério da Justiça (1984-1990). Atualmente é Presidente da Associação de Músicos, Arranjadores e Regentes - AMAR - e membro do Consejo do Comité Latinoamericano e do Caribe da Confederacion Internacional de Autores e Compositores - Cisac. Tem inúmeros discos gravados e é autor de trilhas sonoras para teatro e cinema, incluindo mais de 20 longas-metragens exibidos nacional e internacionalmente.

Texto recebido em 13 de janeiro de 2022; aprovado em 15 de janeiro de 2022.

LOPEZ, Telê Porto Ancona. Mário de Andrade: ramais e caminhos. São Paulo: Livraria Duas Cidades, 1972.

MÁRIO de Andrade, os 70 anos da morte da figura central do Modernismo. Sul 21, 28 fev. 2005. Disponível em: <https://sul21.com.br/areazero-3/2015/02/mario-de-andrade-os-70-anos-da-morte-da-figura-central-do-modernismo>. Acesso em: 8 jan. 2022.

PEREIRA, Maria Elisa. Lundu do escritor difícil: canto nacional e fala brasileira na obra de Mário de Andrade. São Paulo: Editora Unesp, 2006.

PEREIRA DE MELLO, Guilherme Theodoro. A música no Brasil desde os tempos da colônia ao primeiro decênio da República. Salvador: Typographia de São Joaquim, 1908.

RODRIGUES, Leandro Garcia. As intrigas no Modernismo brasileiro: relatos epistolares e vida literária. Revista Uniabeu, v. 6, n. 14, 2013. Disponível em: <https://revista.uniabeu.edu.br/index.php/RU/ article/view/966>. Acesso em: 9 jan. 2022.

TRAVASSOS, Elizabeth. Os mandarins milagrosos: arte e etnografia em Mário de Andrade e Béla Bartok. Rio de Janeiro: Funarte; Jorge Zahar, 1997.

WISNIK, José Miguel. O coro dos contrários: a música em torno da Semana de 22. São Paulo: Livraria Duas Cidades, 1977. 